\title{
Identification of uranium targets based on airborne radiometric data analysis by using multifractal modeling, Tark and Avanligh 1:50000 sheets, NW Iran
}

\author{
P. Afzal ${ }^{1,3}$, A. Zia Zarifi ${ }^{2}$, and A. Bijan Yasrebi ${ }^{3}$ \\ ${ }^{1}$ Department of Mining Engineering, South Tehran branch, Islamic Azad University, Tehran, Iran \\ ${ }^{2}$ Department of Mining Engineering, Lahijan Branch, Islamic Azad University, Lahijan, Iran \\ ${ }^{3}$ Camborne School of Mines, University of Exeter, Penryn, UK \\ Correspondence to: A. Zia Zarifi (afsharzarifi@gmail.com)
}

Received: 18 November 2011 - Revised: 11 March 2012 - Accepted: 24 March 2012 - Published: 16 April 2012

\begin{abstract}
Airborne geophysical anomaly separation using conventional statistics and the fractal/multifractal concentration-area (C-A) method has been applied to the Tark and Avanligh 1:50 000 sheets in NW Iran. The geophysical survey that resulted in the airborne geophysical data was conducted for uranium exploration in both areas. Selected anomalies were further investigated by using surface radiometric data. Firstly, threshold values to define anomalies were determined and compared by means of conventional statistical methods. Several relatively large anomalies were identified with uranium (U) equal to $1.7 \mathrm{eppm}$ and $1.9 \mathrm{eppm}$ in the Tark and Avanligh areas, respectively; locally these U anomalies have magnitudes exceeding 3.5 eppm in both areas. Log-log plots obtained for the C-A method indicate existence of two separate stages of $\mathrm{U}$ enrichment, with a major event being the cause of $U$ concentration values above 6.1 and $3.4 \mathrm{eppm}$ in the Tark and Avanligh areas, respectively. These higher intensity anomalies are located in the northwestern part of the Tark and in the southern part of the Avanligh sheets. In both areas, the C-A anomalies were further investigated using ground radiometric data and XRF analysis revealing higher than 150 and $280 \mathrm{ppm} U$ concentration values in the two areas, respectively. Correlation between the anomalies and geological units show that the anomalies are associated with limestone and sandstone units.
\end{abstract}

\section{Introduction}

Airborne geophysical data especially gamma ray spectrometry are utilized to identify uranium targets (Raghuwanshi, 1992). Interpretation of this data is important for mineral exploration, specifically radioactive elements. Several methods have been conducted for interpretation of geophysical airborne data (Abd El Nabi, 1995; Ranjbar et al., 2001; Tourlière et al., 2003; Airo and Mertanen, 2008). Statistical methods are customized for determination of uranium anomaly locations and extensions. Statistical analysis was applied to the airborne spectrometric data for separation of uranium anomalies from background (Abd El Nabi, 1995; Asfahani et al., 2009). In traditional statistical methods, threshold values are calculated in regard to mean and standard deviation or median based on a normal or lognormal distribution. These methods indicate normality or log-normality which does not consider the shape, extent and magnitude of anomalous areas (Rafiee, 2005; Afzal et al., 2010). In addition, geological and geochemical conditions do not have any effect on the geophysical or geochemical anomaly separation from background (Reimann et al., 2005).

Fractal geometry is a Non-Euclidean geometry established by Mandelbrot (1983) and has been applied in geosciences and mineral exploration, especially in geophysical and geochemical exploration since 1980s, e.g. Turcotte (1989), Meng and Zhao (1991), Bolviken et al. (1992), Schloz and Mandelbrot (1992), Korvin (1992), Cheng et al. (1994), Barton and La Pointe (1995), Agterberg et al. (1996), Turcotte (1997), Cheng (1999), Li et al. (2003), Turcotte (2004), Daya Sagar et al. (2004), Dimri (2005) and 
Shen et al. (2009). In this study, concentration-area (C-A) fractal method was used in order to explain the geophysical airborne data, including $\mathrm{U}$ (eppm) from the Tark and Avanligh 1:50000 sheets, NW Iran. Ultimately, results from C-A fractal method for the U element were compared with geological particulars and surface spectrometry surveys.

\section{Concentration-area fractal method}

Cheng et al. (1994) proposed concentration-area (C-A) method which is employed to define the geophysical background and anomalies. The method has the general form as follow

$A(\rho \leq v) \infty \quad \rho^{-a 1} ; A(\rho \geq v) \quad \infty \quad \rho^{-a 2}$

where $A(\rho)$ denotes the area with concentration values greater than the contour value $\rho, v$ represents the threshold and $a_{1}$ and $a_{2}$ are characteristic exponents. The breaks between straight line segments in C-A log-log plot and the corresponding values of $\rho$ are known as thresholds to separate geophysical values into different components representing different causal factors such as, lithological differences, geochemical processes and mineralizing events (Lima et al., 2003). The C-A method serves to depict the relationship between element concentration values and geological data. The most useful feature of the C-A method is its capability to compute anomaly thresholds (Goncalves et al., 2001).

Multifractal models are utilized to quantify patterns such as geophysical data. Fractal and multifractal modeling are widely applied to eliminate the different mineralized zones (Cheng, 2007). Multifractal theory could be interpreted as a theoretical framework that explains the power law relationships between areas enclosing concentrations below a given threshold value and the actual concentrations itself. To demonstrate and prove that data distribution has a multifractal nature, an extensive computation is required (Halsey et al., 1986; Evertz and Mandelbrot, 1992). This method has several constrains especially when the boundary effects on irregular geometrical data sets are involved (Agterberg et al., 1996; Goncalves, 2001; Cheng, 2007; Xie et al., 2010). Multifractal modelings in geophysical and geochemical exploration help to find exploration targets and mineralization potentials in different types of deposits (Yao and Cheng, 2011). The C-A method seems to be equally applicable to all cases which means that geophysical distributions mostly satisfy the properties of a multifractal function. There is some evidence that geophysical and geochemical data distributions have fractal behavior in nature, e.g. Bolviken et al. (1992), Turcotte (1997), Goncalves (2001), Gettings (2005), Li and Cheng (2006) and Afzal et al. (2010). This theory improves the development of an alternative interpretation validation and useful methods to be applied to geophysical distributions analysis.

\section{Geological setting of the case studies}

Both study areas are located in a major Iranian magmatic belt named Uriumia-Dokhtar, which hosts many metallic deposits (Afzal et al., 2010). There are several prospects and one $\mathrm{Pb}$ $\mathrm{Zn}-\mathrm{Cu}$ mine named Baichehbagh. The Tark and Avanligh 1:50000 sheets are situated in Eastern Azerbaijan, Eastern Mianeh as depicted in Fig. 1. Regional geological studies in these areas by Lotfi (1975) revealed that major lithological units are Eocene, Miocene and Oligocene magmatic and volcanosedimentary rocks. Magmatic units consist of quartz diorite, granite and syenite, as illustrated in Fig. 1 (Lotfi, 1975; Zia Zarifi, 2009). Miocene sedimentary units include marl, sandstones, conglomerates, siltstones and limestones in SE part of the area. There are several metamorphic rocks including andalosite schist, mica schist and marbles (Fig. 1). Light limestone field observations in these sheets show a potential for radioactive elements based on Zia Zarifi (2009). Additionally, sandstone and shale units illustrate uranium enrichment in Tark 1:50 000 sheet (Zia Zarifi, 2009).

\section{Geophysical airborne analysis}

23000 Geophysical airborne data were collected by Austrex Co. in a grid with $1000 \times 500 \mathrm{~m}$ distance between air route surveys during 1976 to 1978 . Line spacing between flight lines is $500 \mathrm{~m}$ with line direction of 41 degrees and sample intervals of $1 \mathrm{~s}$. Detected parameters of these data include $\mathrm{U}_{235}, \mathrm{Th}_{232}$ and $\mathrm{K}_{40}$.

\subsection{Statistical analysis}

One of the most important methods to separate background from different anomalies is the method based on classical statistics. This method is depended on data distribution (Davis, 2002). Different anomalies can be separated in normal distribution, but geophysical and geochemical data do not have normal distribution in most of the cases, e.g. Abd El Nabi, 1995; Ranjbar et al., 2001; Davis, 2002; Li et al., 2003; Rafiee, 2005 and Afzal et al., 2010.

Uranium histograms were drawn for Tark and Avanligh 1:50000 sheets, as presented in Fig. 2. Uranium distribution in Tark sheet is not normal but normal distribution is present in Avanligh sheet. Based on statistical method, uranium threshold in Tark 1:50000 sheet is equal to median and there are two societies, namely background and anomaly. Threshold value for uranium based on radiometric data is 2.17 eppm and different anomalies cannot be separated in this sheet (Table 1). According to the normal distribution of $U$ airborne data in Avanligh sheet, different anomalies were recognized by using formulas based on mean $(M)$ and standard deviation (SD). Uranium threshold value is equal to summation of mean and standard deviation which is $2.59 \mathrm{eppm}$. Low intensity and high intensity anomaly 


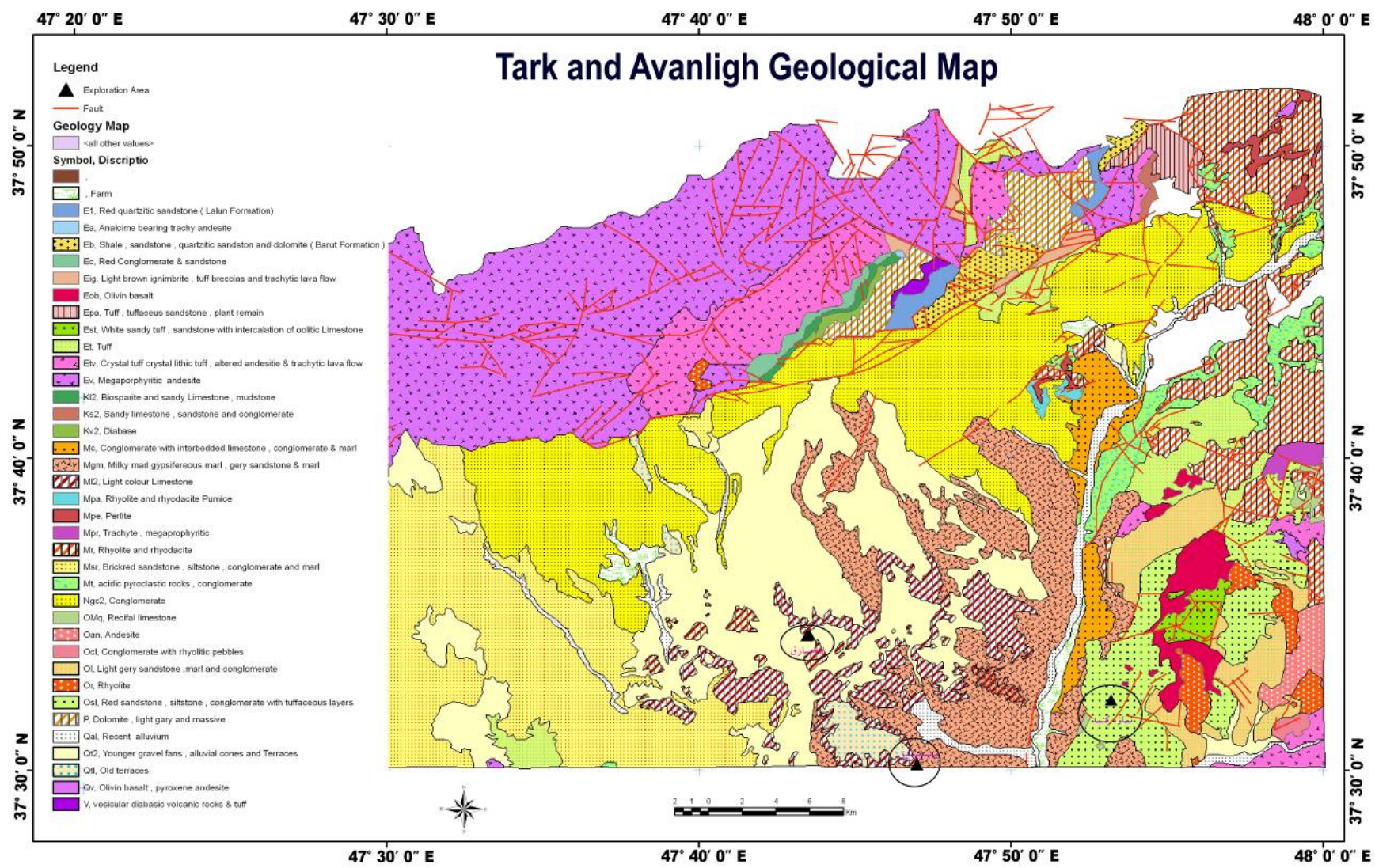

Fig. 1. Tark and Avanligh geological map (Zia Zarifi et al., 2010).

Table 1. Statistical parameters of radiometric geophysical raw data in Tark area.

\begin{tabular}{ll}
\hline Statistical parameter & $\mathrm{U}($ eppm) \\
\hline Men & 2.17 \\
Median & 2.02 \\
SD & 0.84 \\
SV & 0.70 \\
Maximum & 10.23 \\
Minimum & 0.12 \\
\hline
\end{tabular}

SD: standard deviation, SV: sample variance.

thresholds are equal to $M+2 \mathrm{SD}$ (3.05 eppm) and $M+3 \mathrm{SD}$ (3.52 eppm), respectively, as depicted in Table 2.

Uranium distribution maps in these sheets were generated by Surfer8 software in terms of inverse distance squared (IDS), and uranium was classified to different populations based on classical statistics method, as illustrated in Fig. 3. The studied areas were gridded to $250 \times 250 \mathrm{~m}$ cells for evaluation of uranium distribution in both sheets. Uranium anomaly in Tark sheet is huge with respect to its size. Based on this method, different grades of anomalies cannot separate in Tark area. Anomalies of uranium in Avanligh area are
Table 2. Statistical parameters of radiometric geophysical raw data in Avanligh area.

\begin{tabular}{ll}
\hline Statistical parameter & $\mathrm{U}($ eppm $)$ \\
\hline Mean & 2.13 \\
Median & 2.10 \\
SD & 0.46 \\
SV & 0.21 \\
Maximum & 4.81 \\
Minimum & 0.62 \\
\hline
\end{tabular}

SD: standard deviation, SV: sample variance.

situated in small parts of northern, southern and specifically in SE parts of this sheet. High intensity anomalies, more than 4.68 eppm, are located in very small parts of southern and SE area (Fig. 3).

\subsection{C-A method}

C-A log-log plots of uranium were constructed in Tark and Avanligh 1:50 000 sheets, as depicted in Fig. 4. Geophysical populations were divided based on linear segments and breakpoints in these log-log plots, as shown in Fig. 4. Uranium distribution in Tark area indicates a multifractal model 


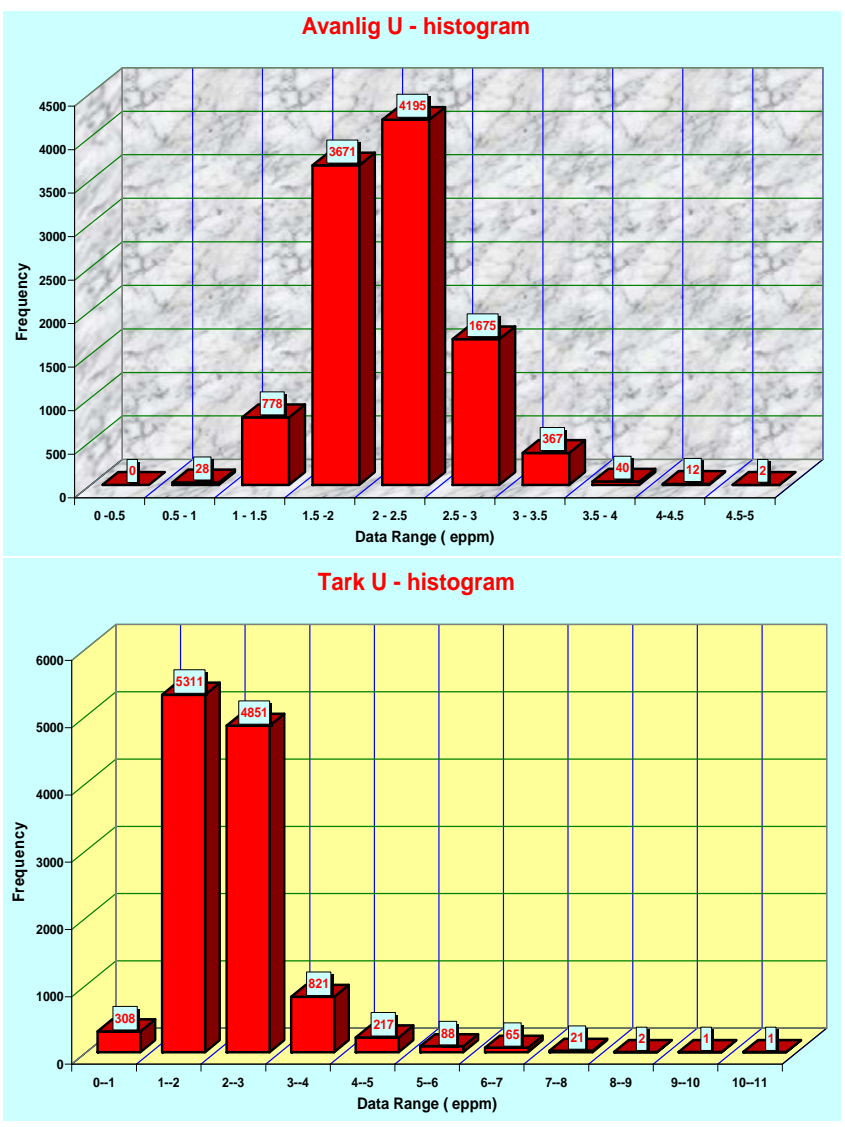

Fig. 2. Histograms of uranium in Tark and Avanligh 1:50 000 sheets.

based on its log-log plot. On the other hand, two phases for uranium mineralization are present in this area. Uranium threshold values are 1.7, 3.5 and $6.1 \mathrm{eppm}$ which are low threshold, moderate intensity anomaly threshold and high intensity anomaly threshold values, respectively, as illustrated in Table 3. C-A log-log plot in Avanligh 1:50 000 sheet represents three breakpoints and four geophysical populations as depicted in Fig. 4. Low intensity threshold value is equal to 1.9 eppm, and moderate intensity and high intensity anomalies threshold values equal to 2.6 and 3.4 eppm, respectively.

Uranium distribution maps in these two areas were generated by Surfer 8, as revealed in Fig. 5. Uranium high intensity anomalies, higher than $6.1 \mathrm{eppm}$, are situated in NE of Tark 1:50000 sheet and moderate intensity anomalies, between 3.5 and 6.1 eppm, are located in central, north and NE parts of this area. High intensive anomalies, higher than 3.4 eppm, occur in small parts in south and SE in Avanligh 1:50 000 sheet, as represented in Fig. 5. Moderate intensive anomalies (1.9-3.5 eppm) are situated in northen and SE parts of this sheet, as depicted in Fig. 5.

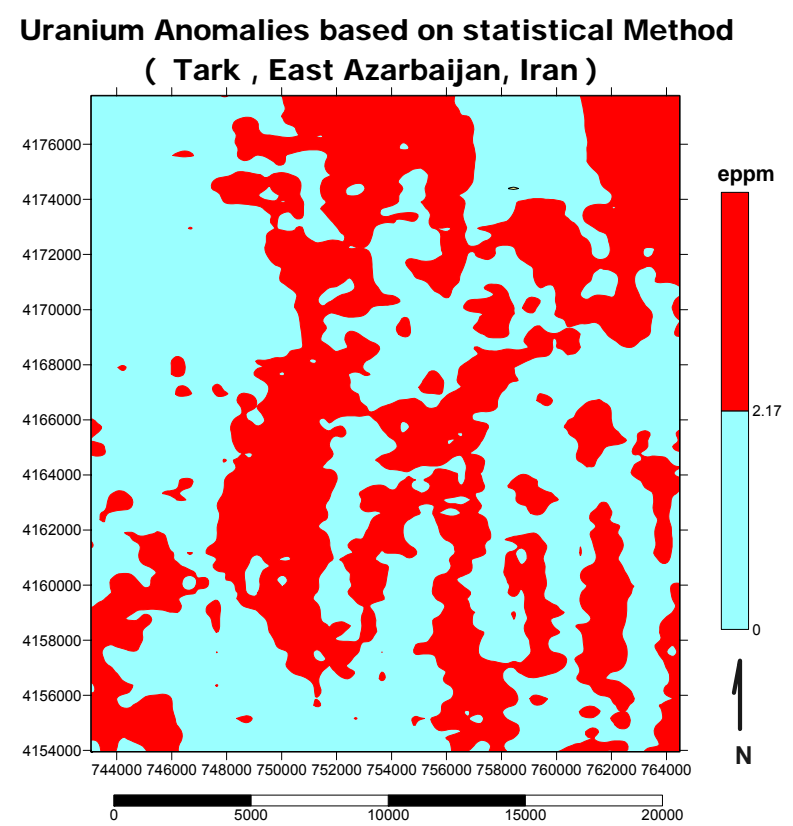

Uranium Anomalies based on statistical Method (Avanligh, East Azarbaijan, Iran )

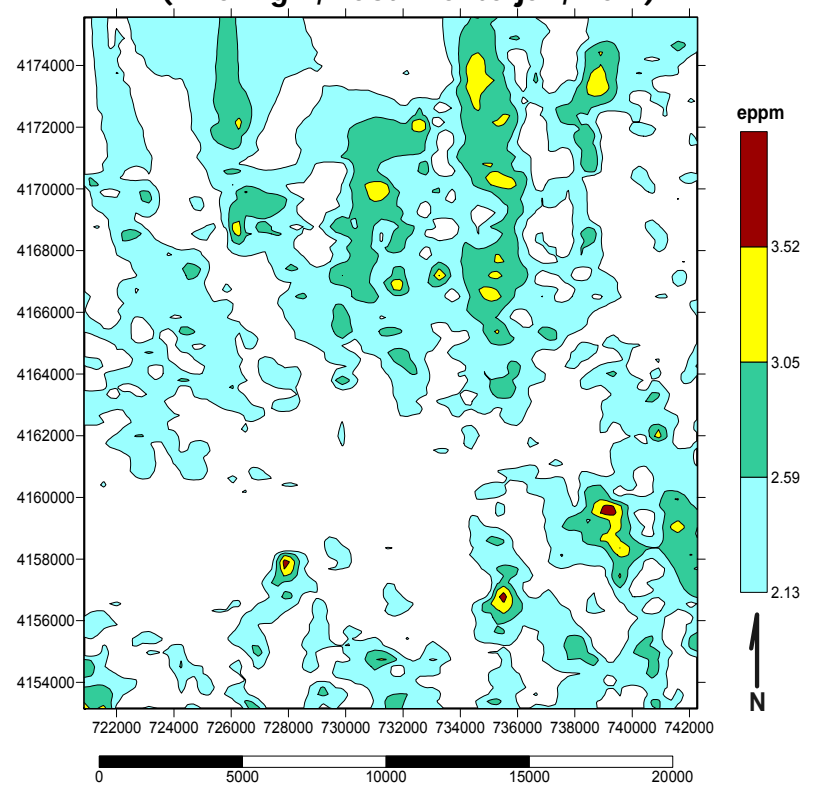

Fig. 3. Uranium anomalies distribution based on statistical methods in Tark and Avanligh sheets.

Table 3. Thresholds of uranium (eppm) in Tark and Avanligh 1:50000 sheet based on C-A fractal method.

\begin{tabular}{lll}
\hline Avanligh & Tark & Thresholds \\
\hline 1.9 & 1.7 & Low intensity threshold \\
2.6 & 3.5 & Moderate intensity threshold \\
3.4 & 6.1 & High intensity threshold \\
\hline
\end{tabular}


Tark 1:50000 sheet

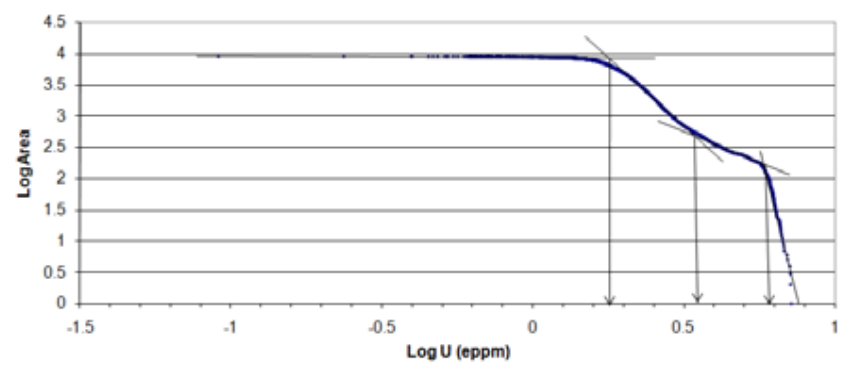

Avanligh 1:50000 sheet

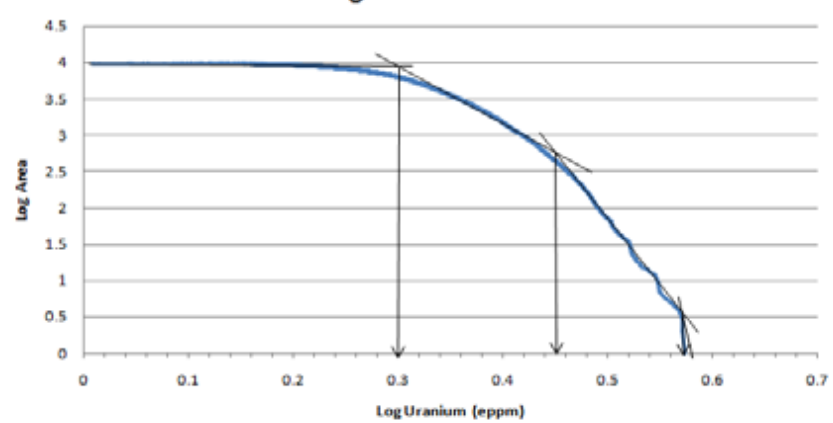

Fig. 4. Log-log plot for $U$ in Tark and Avanligh sheets.

\section{Control with geological particulars, ground radiometric surveying and XRF analysis}

Several high and moderate intensive anomaly results from C-A model were examined and controlled by ground radiometric surveying. Surface radiometric data surveyed from Tark and Avanligh are 10 and 5 points, respectively (Table 4). Ground radiometric data collected from C-A moderate anomalies in Tark sheet show U concentration between 32.6 and $80.2 \mathrm{eppm}$. Spectrometric data from high intensive anomalies in NW of Tark area illustrate that there is U higher than 100 eppm (Table 4). Radiometric data surveyed from high intensive anomalies of Avanligh sheet certifie U higher than $250 \mathrm{eppm}$. Moreover, surface radiometric data collected from moderate intensity anomalies are between 103 and $140 \mathrm{eppm}$. The results reveal there is a positive correlation between anomalies derived via C-A method and surface radiometrical surveying in Table 4. Based on this study, anomalies associated with red sandstone are siltstone, conglomerates, tuffaceous layers units and marls in Tark 1:50 000 sheet. Miocene limestones, Oligocene ryolite and rhyodacite host $\mathrm{U}$ anomalies, specifically the high intensive anomalies in Avanligh area. In addition, Miocene sedimentary units have a good correlation with $U$ anomalies obtained from C-A fractal method in Tark area. However, volcanic rocks are abundant in Avanligh 1:50 000 sheet which can be a source rock in the north part of the area. Major $\mathrm{U}$ anomalies derived by $\mathrm{C}-\mathrm{A}$ model are situated in red

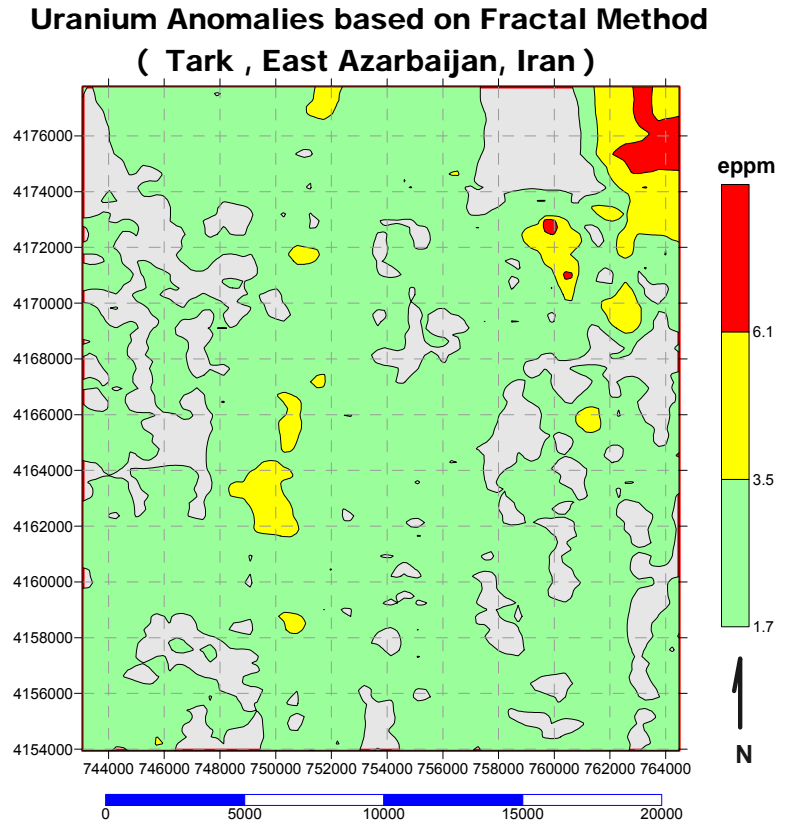

Uranium Anomalies based on Fractal Method ( Avanligh, East Azarbaijan, Iran)

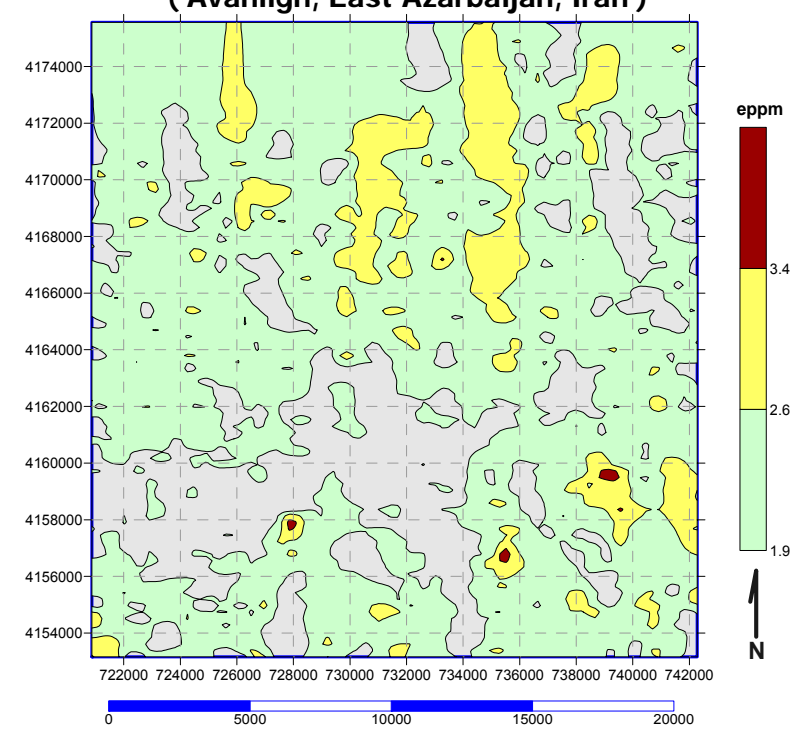

Fig. 5. Uranium anomalies based on C-A method in Tark and Avanligh sheets.

Miocene sandstones and limestones in Tark and Avanligh 1:50 000 sheets, respectively.

Collected samples from these anomalous points were analyzed by XRF method. Chemical analysis shows that the high intensity anomalous parts obtained by C-A method have $\mathrm{U}$ concentration higher than $150 \mathrm{ppm}$ in 86-AZ-TA-04, 86AZ-TA-06, 86-AZ-TA-09 and 86-AZ-TA-09 (Table 4). U concentrations from collected samples of Avanligh area illustrate the high intensity anomalies with the $\mathrm{U}$ grade of higher than $280 \mathrm{ppm}$, as depicted in Table 4. 
Table 4. The coordinates of sampling points in Tark and Avanligh areas.

\begin{tabular}{llr}
\hline $\begin{array}{l}\text { Sample } \\
\text { name }\end{array}$ & $\begin{array}{l}\text { C-A anomaly } \\
\text { intensity }\end{array}$ & $\begin{array}{r}\mathrm{U} \\
\text { (eppm) }\end{array}$ \\
\hline 86-AZ-TA-01 & Moderate & 32.6 \\
86-AZ-TA-02 & Moderate & 37.0 \\
86-AZ-TA-03 & Moderate & 55.4 \\
86-AZ-TA-04 & High & 107.6 \\
86-AZ-TA-05 & Low & 13.1 \\
86-AZ-TA-06 & High & 200.3 \\
86-AZ-TA-07 & Low & 6.3 \\
86-AZ-TA-08 & Moderate & 80.2 \\
86-AZ-TA-09 & High & 112.5 \\
86-AZ-TA-10 & High & 300.4 \\
86-AZ-AV-01 & Moderate & 132.4 \\
86-AZ-AV-02 & Moderate & 139.9 \\
86-AZ-AV-03 & High & 298.6 \\
86-AZ-AV-04 & High & 279.3 \\
86-AZ-AV-05 & Moderate & 103.3 \\
\hline
\end{tabular}

\section{Conclusions}

Study on Tark and Avanligh 1:50 000 sheets reveal the potential use of the C-A method for geophysical airborne anomaly separation as an appropriate tool for geophysical and mineral exploration. The advantages of this method are in its simplicity and easy computational implementation, as well as the possibility to compute a numerical value of the anomalous threshold; which is the most fundamental criteria for cross examination of information with numerical data from different sources, generally used in airborne radiometric data.

Log-log plots in both of the areas show a multifractal model for U. Uranium anomalies result from C-A method and statistical methods were compared in Tark and Avanligh areas. Anomalies resulting from classical statistics methods show only an anomaly in many parts, but most anomalous parts from C-A method are low intensity, between 1.7 and $3.5 \mathrm{eppm}$. High and moderate intensive anomalies are situated in few parts in central and NE of the area. Uranium anomalies resulting in Avanligh area based on classical statistics are similar to anomalies from C-A method because uranium distribution in this sheet is normal. High and moderate intensity anomalous parts from both methods are correlated in southern, especially in SE parts of this area. According to correlation between geological particulars and uranium anomalies obtained from C-A method, Miocene sedimentary units and Oligocene magmatic rock types host the anomalies in Tark and Avanligh 1:50000 sheets. Moreover, high intensive anomalies occur in limestones and red sandstones in the Avanligh and Tark areas, respectively.

There is a very good correlation between the calculated anomalous threshold values and the range of concentrations obtained by the ground radiometric surveying, especially for $\mathrm{U}$ in these areas. High intensity anomalous parts, obtained from C-A method, in Tark area show there are concentrations higher than 100 eppm in surface radiometric data. Surface radiometric data from Avanligh depicted higher than 250 eppm for high intensity anomalies resulted by multifractal model. Based on these studies, uranium targets were identified in NW of Tark and southern part of Avanligh 1:50000 sheets. Also, results of analyzed samples by XRF method reveal uranium concentrations are higher than 150 and $280 \mathrm{ppm}$ in Tark and Avanligh 1:50 000 sheets, respectively.

It may be easy to study geophysical airborne anomalies with the C-A method although multifractal nature of C-A $\log -\log$ curves can be a sufficient way for geophysists to conduct such research in order to find targets with enriched radioactive elements. The developments in multifractal theory and its utilization are highly recommended for stochastic simulation of geophysical distributions.

Acknowledgements. The authors wish to acknowledge research deputy of Islamic Azad University, Lahijan branch for supporting the study and Bijan Esfandiari for helping to editing and S. R. Alavi for helping to data treatment.

Edited by: S.-A. Ouadfeul

Reviewed by: E. J. M. Carranza and two other anonymous referees

\section{References}

Abd El Nabi, S. H.: Statistical evaluation of airborne gamma ray spectrometric data from the Magal Gebriel area, south Eastern Desert, Egypt, J. Appl. Geophys., 34, 47-54, 1995.

Afzal, P., Khakzad, A., Moarefvand, P., Rashidnejad Omran, N., Esfandiari, B., and Fadakar Alghalandis, Y.: Geochemical anomaly separation by multifractal modeling in Kahang (Gor Gor) porphyry system, Central Iran, J. Geochem. Explor., 104, 34-46, 2010.

Agterberg, F. P., Cheng, Q., Brown, A., and Good, D.: Multifractal modeling of fractures in the Lac du Bonnet batholith, Manitoba, Comput. Geosci., 22, 497-507, 1996.

Airo, M. L. and Mertanen, S.: Magnetic signatures related to orogenic gold mineralization, Central Lapland Greenstone Belt, Finland, J. Appl. Geophys., 64, 14-24, 2008.

Asfahani, J., Al-Hent, R., and Aissa, M.: Uranium statistical and geological evaluation of airborne spectrometric data in the Al-Awabed region and its surroundings (Area-3), Northern Palmyrides, Syria, Appl. Radiat. Isotopes, 67, 654-663, 2009.

Barton, C. C. and La Pointe, P. R.: Fractals in the earth sciences, Plenum Press, New York, 265 pp., 1995.

Bolviken, B., Stokke, P. R., Feder, J., and Jossang, T.: The fractal nature of geochemical landscapes, J. Geochem. Explor., 43, 91109, 1992.

Cheng, Q.: Spatial and scaling modelling for geochemical anomaly separation, J. Geochem. Explor., 65, 175-194, 1999.

Cheng, Q.: Multifractal imaging filtering and decomposition methods in space, Fourier frequency, and eigen domains, Nonlin. Processes Geophys., 14, 293-303, doi:10.5194/npg-14-293-2007, 2007. 
Cheng, Q., Agterberg, F. P., and Ballantyne, S. B.: The separartion of geochemical anomalies from background by fractal methods, J. Geochem. Explor., 51, 109-130, 1994.

Daya Sagar, B. S., Rangarajan, G., and Veneziano, D.: Fractals in Geophysics, Chaos, Soliton. Fract., 19, 237-239, 2004.

Davis, J. C.: Statistics and data analysis in Geology, 3rd Edn., John Wiley \& Sons Inc., New York, 2002.

Dimri, V. P.: Fractal Behavior of the Earth System, Springer, 208 pp., 2005.

Evertz, C. J. G. and Mandelbrot, B. B.: Multifractal measures (appendix B), in: Chaos and Fractals, edited by: Peitgen, H.-O., Jurgens, H., and Saupe, D., Springer, New York, 1992.

Gettings, M. E.: Multifractal magnetic susceptibility distribution models of hydrothermally altered rocks in the Needle Creek Igneous Center of the Absaroka Mountains, Wyoming, Nonlin. Processes Geophys., 12, 587-601, doi:10.5194/npg-12-5872005, 2005.

Goncalves, M. A.: Characterization of geochemical distributions using multifractal models, Math. Geol., 33, 41-61, 2001.

Goncalves, M. A., Mateus, A., and Oliveira, V.: Geochemical anomaly separation by multifractal modeling, J. Geochem. Explor., 72, 91-114, 2001.

Halsey, T. C., Jensen, M. H., Kadanoff, L. P., Procaccia, I., and Shraiman, B. I.: Fractal measures and their singularities: The characterization of strange sets. Phys. Rev. A, 33, 1141-1151, 1986.

Korvin, G.: Fractal Models in the Earth Science, Elsevier, Amsterdam, 396 pp., 1992.

Li, Q. and Cheng, Q.: VisualAnomaly: A GIS-based multifractal method for geochemical and geophysical anomaly separation in Walsh domain, Comput. Geosci., 32, 663-672, 2006.

Li, C., Ma, T., and Shi, J.: Application of a fractal method relating concentrations and distances for separation of geochemical anomalies from background, J. Geochem. Explor., 77, 167-175, 2003.

Lima, A., De Vivo, B., Cicchella, D., Cortini, M., and Albanese, S.: Multifractal IDW interpolation and fractal filtering method in environmental studies: an application on regional stream sediments of (Italy), Campania region, Appl. Geochem., 18, 1853-1865, 2003.

Lotfi, M.: Study on geology and petrology in Mianeh area, Unpublished Msc thesis, Tehran University, 230 pp., 1975.

Mandelbrot, B. B.: The Fractal Geometry of Nature, W. H. Freeman, San Fransisco, 468 pp., 1983.
Meng, X. and Zhao, P.: Fractal method for statistical analysis of geological data, Chinese J. Geosci., 2, 207-211, 1991.

Rafiee, A.: Separating geochemical anomalies in stream sediment media by applying combination of fractal concentrationarea model and multivariate analysis (Case study: Jeal-e-Barez 1:100,000 Sheet, Iran), 20th World Mining Congress Proceeding, Iran, 461-470, 2005.

Raghuwanshi, S. S.: Airborne gamma-ray spectrometry in uranium exploration, Adv. Space Res., 12, 77-81, 1992.

Ranjbar, H., Hassanzadeh, H., Torabi, M., and Ilaghi, O.: Integration and analysis of airborne geophysical data of the Darrehzar area, Kerman Province, Iran, using principal component analysis, J. Appl. Geophys., 48, 33-41, 2001.

Reimann, C., Filzmoser, P., and Garrett, R. G.: Background and threshold: critical comparison of methods of determination, Sci. Total Environ., 346, 1-16, 2005.

Scholz, C. and Mandelbrot, B. B.: Special issue on fractals in geology and geophysics, Pure Appl. Geophys., 131, 96-171, 1992.

Shen, W., Fang, C., and Zhang, D.: Fractal and Chaos Research of Geomagnetic Polarity Reversal, Earth Sci. Front., 16, 201-206, 2009.

Turcotte, D. L.: Fractals in geology and geophysics, Pure Appl. Geophys., 131, 171-196, 1989.

Turcotte, D. L.: Fractals and Chaos in Geology and Geophysics, Cambridge University Press, Cambridge, 398 pp., 1997.

Turcotte, D. L.: The relationship of fractals in geophysics to "the new science", Chaos, Soliton. Fract., 19, 255-258, 2004.

Tourlière, B., Perrin, J., Le Berre, P., and Pasquet, J. F.: Use of airborne gamma-ray spectrometry for kaolin exploration, J. Appl. Geophys., 53, 91-102, 2003.

Xie, S., Cheng, Q., Zhang, S., and Huang, K.: Assessing microstructures of pyrrhotites in basalts by multifractal analysis, Nonlin. Processes Geophys., 17, 319-327, doi:10.5194/npg-17319-2010, 2010.

Zia Zarifi, A.: Regional uranium exploration in 1:50000 sheets of Tark and Avanligh areas in Eastern Azerbaijan Province, Iran, Unpublished PhD thesis, Islamic Azad University, Science and research branch, 287 pp., 2009.

Zia Zarifi, A., Afzal, P., and Darvishzadeh, A.: Separating geophysical anomalies in airborne radiometric data by applying fractal concentration-area model, Tark 1:50,000 Sheet, NW Iran, Proceeding of International Mining Congress \& Expo 2010 (Abstract Volume), p. 20, 2010.

Yao, L. and Cheng, Q.: Multi-scale interactions of geological processes during mineralization: cascade dynamics model and multifractal simulation, Nonlin. Processes Geophys., 18, 161-170, doi:10.5194/npg-18-161-2011, 2011. 